\title{
Pembuatan nata de cassava dari limbah cair tapioka dengan menggunakan sumber nitrogen alami yang berbeda
}

\author{
Production of nata de cassava from tapioca starch wastewater using different \\ natural sources of nitrogen
}

\author{
Cory Dian Alfarisi, Yelmida, Ida Zahrina*, Anisa Mutamima \\ Department of Chemical Engineering, Faculty of Engineering, Universitas Riau, Pekanbaru, Indonesia
}

\section{ARTICLE INFO}

Article History

Received: February 19, 2021

Accepted: February 25, 2021

Published: February 26, 2021

\section{Keywords.}

Acetobacter xylinum,

cassava,

nata,

tapioca starch wastewater,

sprouts.

Cite this:

J. IIm. Pertan., 2021, 17 (2) 93-100

DOI:

https://doi.org/10.31849/jip.v17i2.6208

\section{ABSTRACT}

Liquid waste from processing cassava into tapioca starch is carbohydraterich waste and can be used as a growth medium for the Acetobacter xylinum, which is useful in producing one of the fermentation products, i.e. nata. Several factors influence the production of nata, one of them is the addition of nutrients in the form of nitrogen in the fermentation medium. The nitrogen source used is usually from inorganic fertilizers, such as urea and ammonium sulfate. In this study, fermentation of tapioca starch wastewater was developed, using a natural sources of nitrogen derived from soybean and green bean sprouts extract. Nata was made by treating various concentrations of soybean and green bean sprouts extract (3\%, 4\%, 5\%) and fermentation time ( 6 days, 7 days, 8 days, 9 days and 10 days). The characteristics of the nata product were seen from the thickness and yield of the nata. The nata de cassava product's optimum results were tested for thickness, yield, and moisture content. The results showed that the best type of natural nitrogen source was soybean sprouts extract $5 \%$, fermentation time of 10 days with a thickness of $0.55 \mathrm{~cm}$, the water content of $97.58 \%$, and yield of $63.09 \%$.

\section{INTRODUCTION}

Salah satu sumber karbohidrat populer yang menjadi bahan pangan pengganti beras di Indonesia yaitu singkong. Komposisi singkong segar terdiri dari air sekitar 60\%, pati $35 \%$, serat kasar 2,5\%, protein $1 \%$, lemak, o,5\% dan abu $1 \%$ (Litbang, 2011). Singkong, yang merupakan jenis umbi-umbian dapat diolah menjadi tepung, yang dikenal dengan tepung tapioka. Pada proses pembuatan tepung tapioka, dihasilkan limbah cair yang masih memiliki kandungan karbohidrat yang dapat dimanfaatkan lebih lanjut. Misgiyarti (2008) dan Muharam (2014) telah memanfaatkan limbah cair hasil produksi tapioka sebagai bahan baku pembuatan nata. Berdasarkan hasil analisis, limbah cair dari pengolahan singkong menjadi tapioka mengandung karbohidrat 2,5\%, glukosa 0,185 $\mathrm{mg} / \mathrm{L}$, nitrogen total $182 \mathrm{mg} / \mathrm{L}$, serta $\mathrm{pH} 5-5,5$ (Muharam,2014). Hasil analisis ini menunjukkan bahwa limbah cair dari pengolahan singkong dapat dimanfaatkan oleh bakteri Acetobacter xylinum sebagai substrat untuk membuat nata dari singkong atau dikenal dengan sebutan nata de cassava. Selain memanfaatkan limbah cair tapioca ini, penelitian terdahulu telah berhasil membuat nata de cassava langsung dari singkong (Putriana and Aminah, 2013) dan dari kulitnya (Masri et al., 2020).

Nata merupakan salah satu produk fermentasi menggunakan mikroba Accetobacter xylinum. Nata bertekstur kenyal, berwarna putih keruh dan umumnya dimanfaatkan sebagai makanan pencuci mulut karna sifatnya yang ringan. Diversifikasi bahan pangan yang dapat dilakukan dengan memanfaatkan limbah hasil proses pembuatan tepung tapioka salah satunya nata de cassava.

Pengolahan limbah cair tapioka menjadi nata de cassava dapat memberikan dampak positif yaitu meningkatkan nilai tambah dari limbah yang dihasilkan sekaligus dapat membranding produk "baru" nata de cassava. Selain itu, pembuatan nata de cassava dapat

\footnotetext{
*Corresponding Author

E-mail:ida.zahrina@lecturer.unri.ac.id
} 
mengurangi pencemaran lingkungan dari industri tepung tapioka, karena hasil limbah dapat diolah kembali menjadi produk dengan nilai jual yang cukup tinggi (Dianawati, 2009).

Mekanisme pembuatan nata de cassava dimulai dengan pemecahan sukrosa ekstraseluler menjadi gugus glukosa dan fruktosa oleh mikroba. Gugus glukosa dan fruktosa ini yang digunakan untuk metabolisme sel. Acetobacter xylinum juga akan mengeluarkan enzim yang mampu menyusun gugus glukosa menjadi selulosa ekstraseluler yang akan saling terhubung dan membentuk lapisan tipis setelah 24 jam masa inkubasi (Rizal et.al., 2013). Pada proses pembuatan nata, keberadaan unsur nitrogen dan karbon merupakan aspek utama selain pemeliharaan starter, sanitasi dan derajat keasaman $(\mathrm{pH})$.

Tabel 1. Perbandingan kandungan nutrisi kecambah kacang hijau dengan kecambah kacang kedelai per $100 \mathrm{~g}$

\begin{tabular}{|c|c|c|c|}
\hline \multirow{2}{*}{ Jenis Zat Gizi } & \multirow{2}{*}{ Satuan } & \multicolumn{2}{|c|}{ Kecambah } \\
\hline & & Kacang Hijau & Kacang Kedelai \\
\hline Energi & kkal & 34 & 76 \\
\hline Karbohidrat & $\mathrm{g}$ & 4,3 & 6,4 \\
\hline Protein & g & 3,7 & 9 \\
\hline Lemak & $\mathrm{g}$ & 1,2 & 2,6 \\
\hline Air & $\mathrm{g}$ & 90,4 & 81 \\
\hline Kalsium & $\mathrm{mg}$ & 166 & 50 \\
\hline Besi & $\mathrm{mg}$ & 74 & 65 \\
\hline Vitamin C & $\mathrm{mg}$ & 5 & 15 \\
\hline
\end{tabular}

Sumber nitrogen menjadi salah satu faktor penting dalam pembuatan nata. Biasanya sumber nitrogen berasal dari pupuk anorganik, seperti urea dan ammonium sulfat (Hamad dan Kristiono, 2013). Selain itu, kecambah menjadi salah satu sumber nitrogen alami yang dapat digunakan dalam pembuatan nata. Kecambah diartikan sebagai tumbuhan kecil yang baru muncul dari biji. Kelangsungan hidup kecambah masih tergantung pada persediaan makanan yang dapat dalam biji. Ciri selesainya proses perkecambahan adalah tanamannya kecil, tetapi telah mempunyai batang, daun, akar dan akar rambut, serta dapat berkembang menjadi tanaman baru dalam keadaan baik (Kuncara, 2017). Kandungan vitamin pada kacangkacangan seperti vitamin A, B, dan C mengalami peningkatan mulai dari 2,5 sampai 300\% ketika dikecambahkan.

Pada penelitian ini digunakan dua jenis kecambah yang berbeda yaitu kecambah kacang hijau (tauge) dan kacang kedelai. Menurut Kuncara (2017), terdapat perbedaan kandungan nutrisi antara antara kecambah kacang hijau (tauge) dengan kecambah kacang kedelai. Perbandingan antara kandungan nutrisi kedua jenis kecambah tersebut dapat dilihat pada Tabel 1 (Cahyadi, 2007).

Niarda et al. (2015) dan Musdawati et al. (2017) melaporkan kisaran kandungan nitrogen dalam kecambah kacang kedelai dan kacang hijau berturut-turut adalah 20-35\% dan 20,521\%. Dengan adanya perbedaan kandungan ini, pada penelitian ini akan dilihat pengaruh penambahan nutrisi berupa nitrogen dalam media fermentasi nata serta waktu fermentasi pembentukan nata. Untuk uji kualitas nata de cassava yang dihasilkan mengacu kepada Standar Nasional Indonesia (SNI) 01 - 4317 1996 (1996).

\section{MATERIALS AND METHODS}

Bahan dan Alat

Bahan yang digunakan pada penelitian ini adalah limbah cair sintesis berupa filtrate dari hasil penyaringan umbi singkong yang telah dihancurkan), Ekstrak kecambah kacang kedelai, ekstrak kecambah kacang hijau (tauge), gula pasir, asam cuka 99,8\%, starter bakteri Acetobacter xylinum, air. Sedangkan alat-alat yang digunakan pada penelitian ini adalah alatalat gelas, cutter, blender, saringan, botol kaca, panci, spatula, koran bekas, tali rafia, wadah penampung, kompor, cawan porselen dan neraca analitik.

\section{Proses Pembuatan Ekstrak Kacang Hijau (Tauge)/Ekstrak Kecambah Kedelai \\ Masing-masing kecambah yang masih segar ditimbang sebanyak 500 gram, kemudian dicuci dengan menggunakan air bersih. Kecambah tersebut dimasukkan ke dalam blender lalu ditambahkan air sebanyak 1 liter. Campuran kecambah dan air yang telah diblender kemudian disaring menggunakan kain tipis lalu diperas sebagai masing-masing ekstrak kacang hijau (tauge) dan kacang kedelai. Ekstrak kecambah tersebut kemudian dimasukkan ke dalam botol plastik.}




\section{Proses Pembuatan Nata}

Limbah cair tapioka sintesis diambil sebanyak $4365 \mathrm{~mL}$ kemudian direbus di dalam panci stainless hingga mendidih. Tambahkan gula pasir sebanyak 112,5 gram, cuka $45 \mathrm{ml}$ dan ekstrak kecambah sebanyak $135 \mathrm{ml} \mathrm{(3 \%} \mathrm{dari}$ volume total substrat $4500 \mathrm{~mL}$ ). Buih yang muncul di permukaan rebusan air dibuang. Angkat panci dari kompor. Air hasil rebusan dituang ke dalam nampan yang sudah disiapkan dan telah diberi penutup koran sedemikian rupa. Adonan dari limbah tapioka ditunggu sampai suhu ruang. Dari ujung loyang dituangkan bibit nata sebanyak $45 \mathrm{ml}$. Loyang kembali ditutup dan dijaga tidak tergoyang selama proses fermentasi. Perlakuan yang sama dilakukan untuk varibel lainnya dengan lama fermentasi 6 ,
7, 8, 9, dan 10 hari. Kemudian dilakukan pengujian nata berupa rendemen, ketebalan, dan kadar air.

\section{RESULTS AND DISCUSSIONS}

\section{Uji Ketebalan Nata}

Dalam pengujian yang dilakukan pertama kali adalah uji ketebalan nata, yaitu dengan mengukur tingginya nata, lapisan selulosa yang mampu dihasilkan oleh bakteri A. xylinum. Berdasarkan data hasil penelitian yang telah dilakukan, diperoleh hasil rerata pengukuran terhadap ketebalan yang disajikan pada Gambar 1 akibat diberikan sumber nitrogen alami yang berbeda, yaitu dari kecambah kedelai dan kacang hijau:
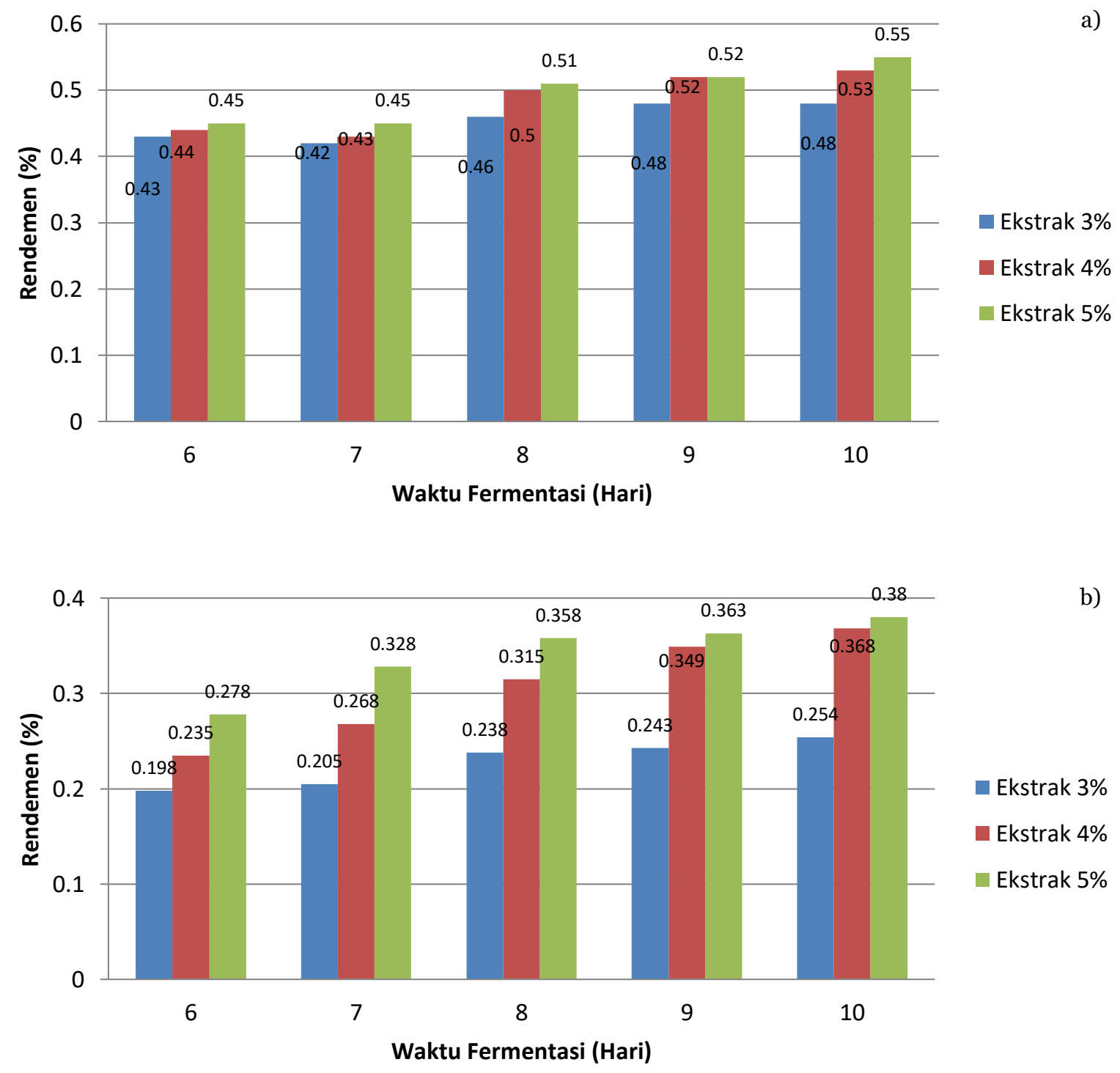

Gambar 1. Hasil ketebalan nata dengan ekstrak a) kecambah kacang kedelai, b) kecambah kacang hijau (tauge) 
Berdasarkan Gambar 1a menunjukkan bahwa ketebalan nata pada hari ke-6 dengan konsentrasi ekstrak kecambah kacang kedelai 3$5 \%$ yaitu $0,43 \mathrm{~cm} ; 0,44 \mathrm{~cm}$; dan $0,45 \mathrm{~cm}$. Hasil ketebalan nata dengan konsentrasi ekstrak kecambah kacang kedelai 5\% pada waktu fermentasi selama 6-10 hari berturut-turut sebesar 0,45 cm; 0,45 cm; 0,51 cm; 0,52 cm; dan $0,55 \mathrm{~cm}$. Sedangkan pada Gambar $1 \mathrm{~b}$ dengan ektrak tauge pada konsentrasi 5\% dengan lama fermentasi 10 hari menghasilkan ketebalan nata $0,25 \mathrm{~cm}, \quad 0,36 \mathrm{~cm}$ dan $0,38 \mathrm{~cm}$. Jika dibandingkan antara Gambar 1a dan 1b pada kosentrasi $5 \%$ dengan lama fermentasi 10 hari maka dapat dilihat bahwa ketebalan nata dengan kecambah kacang kedelai lebih baik dari aspek ketebalannya.
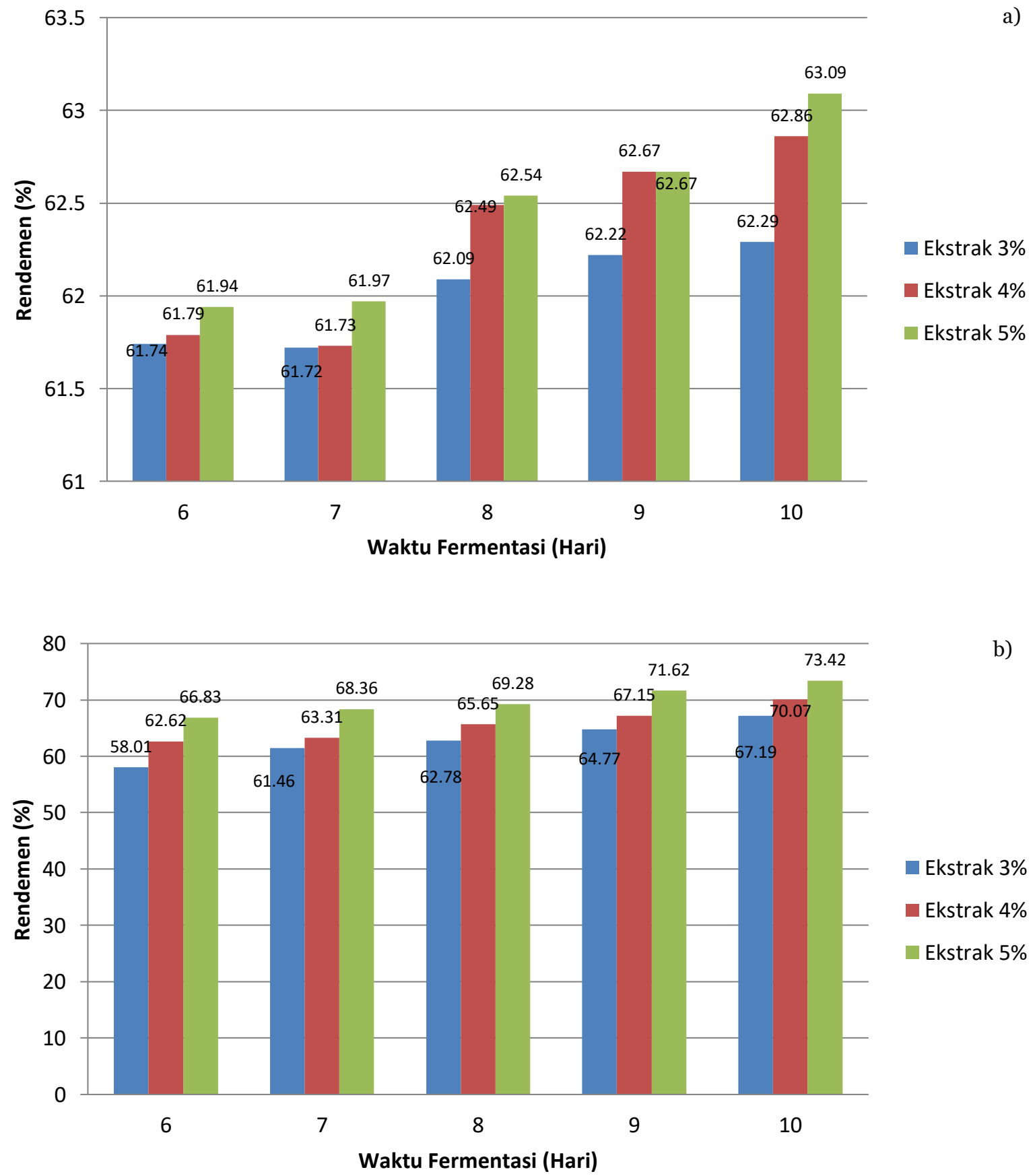

b)

Gambar 2. Pengaruh variasi waktu fermentasi dan konstrasi ekstrak a) kecambah kacang kedelai dan b) kacang tanah terdahap rendemen produk nata de cassava 
Penyebab terjadinya hal tersebut dikarenakan ekstrak kecambah kacang kedelai memiliki kandungan nitrogen yang relatif lebih tinggi, sehingga ekstrak kedelai dapat memenuhi kebutuhan mikroba atau bakteri Acetobacter xylinum. Menurut Prastyana (2002) menyatakan bahwa pada takaran kandungan nitrogen yang sesuai dalam medium akan merangsang bakteri menghasilkan nata dengan ikatan selulosa yang relatif lebih kuat dan tidak mudah lepas. Menurut Nugraheni (2007), faktor lain yang mempengaruhi ketebalan nata de cassava adalah oksigen. Dalam fermentasi aerob, oksigen dipandang sebagai zat nutrisi yang penting dalam produksi nata. Berdasarkan dapat disimpulkan bahwa lama waktu fermentasi juga dapat mempengaruhi ketebalatan nata yang dihasilkan. Dimana data menunjukkan semakin lama waktu fermentasi dan konsentrasi ekstrak kecambah yang digunakan, maka semakin tinggi rerata ketebalan nata yang dihasilkan.

\section{Uji Rendemen Nata}

Uji rendemen nata (\%) dihitung dari hasil bagi antara massa hasil nata dengan massa awal media lalu dikali 100\%, sebagaimana yang dapat dilihat pada Gambar 2, hasil rerata pengukuran terhadap rendemen. Pengukuran rendemen dilakukan agar dapat mengetahui persentase biomassa nata yang dihasilkan dari proses fermentasi media oleh bakteri A. xylinum.

Grafik pada Gambar 2a menunjukkan bahwa konsentrasi ekstrak kecambah kedelai 3\% sampai 5\% memberikan perbedaan pengaruh terhadap rendemen nata de cassava. Grafik diatas terlihat bahwa rendemen nata pada hari ke- 6 dengan konsentrasi ekstrak kecambah kacang kedelai 3$5 \%$ berturut-turut yaitu 61,74\%; 61,79\%; dan $61,94 \%$. Sedangkan hasil rendemen nata dengan konsentrasi ekstrak kecambah kacang kedelai 5\% pada waktu fermentasi selama 6-10 hari berturut-turut sebesar 61,93\%; 61,97\%; 62,54\%; 62,67\%; dan 63,09\%.

Peningkatan hasil rendemen nata diperoleh karena aktivitas Acetobacter xylinum yang mengeluarkan enzim penyusun gugus selulosa ekstraseluler setelah 24 jam masa inkubasi. Untuk pengaruh variasi waktu fermentasi dan konstrasi ekstrak tauge terdahap rendemen produk nata de cassava dapat dilihat pada Gambar 2b. Berdasarkan grafik yang diperoleh dapat dilihat bahwa penambahan ekstrak tauge juga sangat berpengaruh besar terhadap rendemen dan waktu fermentasi. Pada konsentrasi ekstrak tauge 3\%-5\% dengan lama waktu fermentasi 10 hari diperoleh berturutturut sebesar 67,19\%, 70,07\% dan 73,42\%.
Berdasarkan Gambar 2a dan 2b dapat kita lihat bahwa jenis ekstrak kecambah yang digunakan juga dapat berpengaruh terhadap rendemen nata de cassava yang dihasilkan. Dapat dilihat kecambah kacang kedelai pada konsentrasi $5 \%$ dengan lama fermentasi 10 hari menghasilkan rendemen sebesar 63,09\%, sedangkan pada ekstrak tauge dengan konstrasi dan lama waktu fermentasi yang sama menghasilkan rendemen yang lebih besar yaitu $73,42 \%$. Berdasarkan data yang diperoleh ekstrak tauge lebih besar pengaruhnya terhadap rendemen yang dihasilkan.

Selain jenis ekstrak kecambah yang digunakan, konsentrasi ekstrak kecambah juga sangat mempengaruhi besarnya rendemen. Hal ini dikarenakan kandungan protein, mineral dan vitamin yang cukup untuk pertumbuhan bakteri. Bakteri Acetobacter xylinum tidak akan langsung tumbuh dan berkembang saat dipindahkan ke media baru. Bakteri akan menyesuaikan diri dengan substrat dan kondisi lingkungan barunya atau disebut dengan fase adaptasi. Lama fase ini ditentukan oleh medium dan lingkungan pertumbuhan serta jumlah inokulum (Melina, 2016). Maka jika digunakan ektrak kecambah kurang dari 3\% dengan limbah cair tapioka, gula dan asam asetat serta bakteri yang sama maka pada saat fase adaptasi, bakteri akan mengalami kekurangan sumber nitrogen yang dibutukan dalam aktivitas metabolisme serta pembesaran selnya. Hal ini mengakibatkan bakteri tidak mampu memproduksi enzim yang berfungsi membentuk selulosa ekstraseluler. Sebaliknya, jika digunakan ektrak tauge dengan konsetrasi lebih tinggi maka maka nutrien tersebut justru dapat bersifat toksik terhadap mikrobia, sehingga produksi nata tidak maksimal (Putranto, 2017). Dengan demikian penggunaan ektrak tauge yang cukup mampu menggantikan penggunaan ammonium sulfat sebagai sumber nitrogen dalam pembuatan nata.

\section{Uji Kadar Air Nata}

Pernentuan kadar air nata (100\%) dihitung berdasarkan hasil bagi antara selisih massa sampel sebelum dan sesudah dikeringkan dengan massa sampel sebelum dikeringkan lalu dikali 100\%. Produk nata memiliki kadar air yang sangat tinggi. Hal ini disebabkan nata diproduksi oleh bakteri pada medium cair. Berdasarkan analisis statik terdapat pengaruh antara waktu fermentasi dan konsentrasi ekstrak tauge terhadap kadar air nata de cassava yang dihasilkan. Hasil pengujian kadar air produk nata de cassava menggunakan ekstrak kecambah kacang kedelai dan tauge dapat dilihat pada Gambar 5 . 
Grafik pada Gambar 5a menunjukkan bahwa kadar air nata pada hari ke-6 dengan konsentrasi ekstrak kecambah kacang kedelai 3-5\% berturutturut yaitu 95,20\%; 95,27\%; dan 95,75\%. Hasil kadar air nata dengan konsentrasi ekstrak kecambah kacang kedelai 5\% pada waktu fermentasi selama 6-10 hari berturut-turut sebesar 95,75\%; 95,82\%; 96,68\%; 96,99\%; dan 97,58\%. Sedangkan grafik pada Gambar 5b menujukkan bahwa kadar air nata pada hari ke-6 dengan konsentrasi ekstrak tauge 3-5\% berturutturut yaitu 89,87\%; 90,97\% dan 91,44\%. Hasil kadar air nata dengan konsentrasi ekstrak tauge 5\% pada waktu fermentasi selama 6-10 hari berturut-turut sebesar 91,44\%; 91,92\%; 93,26\%; 94,76\%; dan 96,03\%.
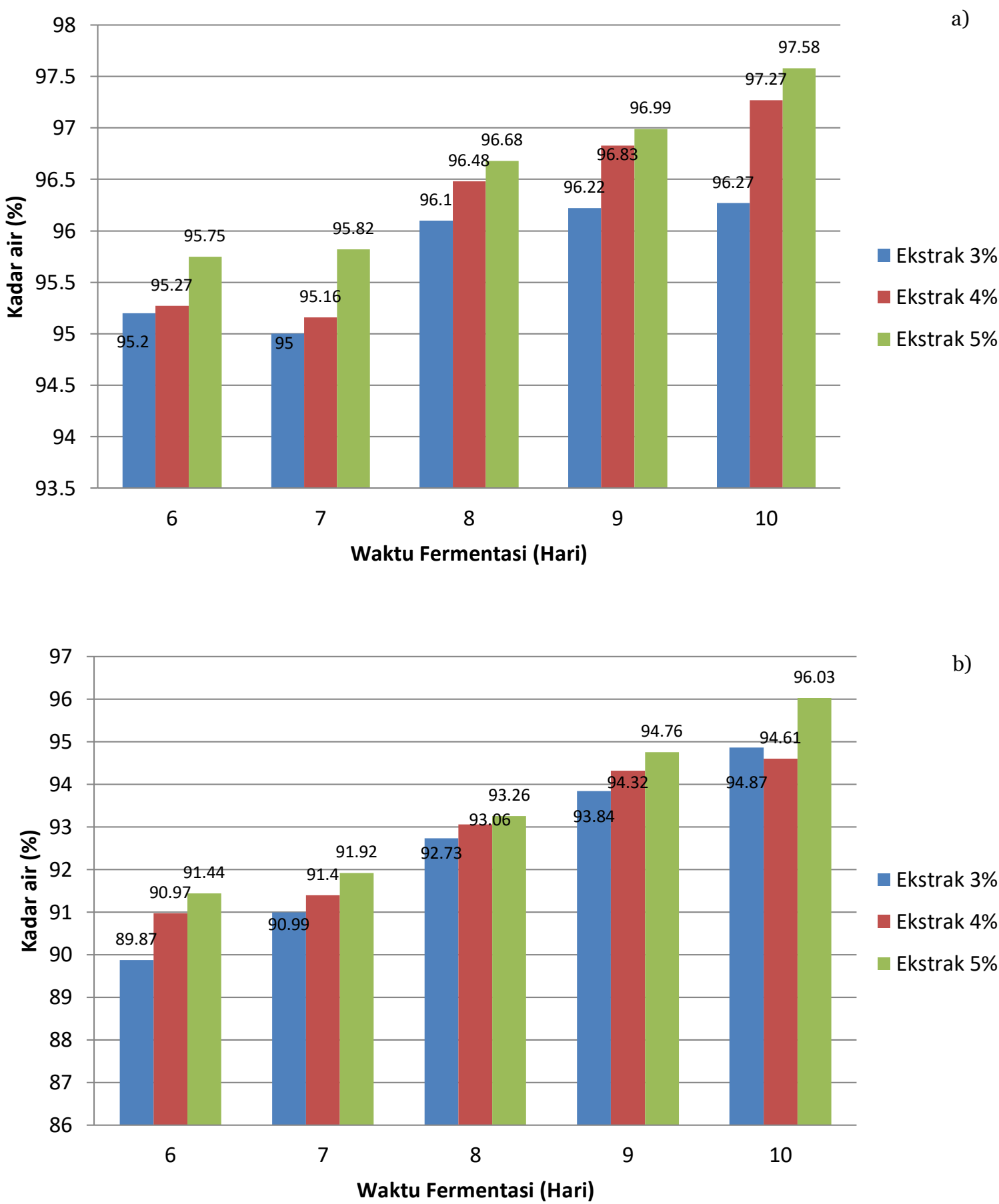

Gambar 5. Pengaruh variasi waktu fermentasi dan konsentrasi ekstrak a) kecambah kacang kedelai dan b) kecambah kacang hijau (tauge) terhadap kadar air produk nata de cassava 
Berdasarkan data dari dua jenis ekstrak kecambah yang berbeda mempengaruhi terhadap kadar air yang dikandung didalam produk nata de cassava. Terlihat bahwa pada konsetrasi $5 \%$ dan lama waktu fermentasi 10 hari pada nata de cassava yang dihasilkan oleh ekstrak kecambah kacang kedelai sebesar 97,58\% sedangkan nata de cassava yang dihasilkan oleh ekstrak kacang hijau (tauge) sebenar 96,03.

Dapat disimpulkan bahwa nata de cassava yang dihasilkan oleh ekstrak kecambah kacang kedelai lebih besar dari pada nata de cassava yang dihasilkan oleh ekstrak kacang hijau (tauge). Hal ini disebabkan karena nata yang tipis mempunyai struktur yang lebih rapat dengan kandungan air yang lebih rendah dibandingkan nata yang tebal, sehingga kadar air pada nata yang tipis lebih rendah. Sebaliknya nata yang tebal mempunyai struktur selulosa yang lebih longgar dengan kandungan air lebih tinggi (Putranto, 2017). Dengan demikian, ketebalan nata juga berpengaruh terhadap kadar air yang dihasilkan. Menurut Effendi (2009), bakteri nata mempolimerisasi glukosa menjadi selulosa dan secara bertahap menutupi permukaan. Selulosa tersebut berbentuk fibril submikroskopik yang kemudian saling terikat tidak beraturan membentuk membran tergelatinasi sehingga mengakibatkan memerangkap air dalam jumlah banyak.

\section{CONCLUSIONS}

Kesimpulan yang diperoleh dari hasil penelitian ini bahwa penggunakan ekstrak kecambah berupa kacang hijau(tauge) dan kedelai dalam pembuatan nata de cassava sangat mempengaruhi ketebalan, rendemen dan kadar air yang dihasilkan. Ekstrak kecambah kacang kedelai memiliki ketebalan serta kadar air yang tinggi dibandingkan ekstrak kecambah kacang kedelai. Namun berbanding terbalik dengan rendemen yang dihasilkan oleh ekstrak kecambah kacang kedelai. Sumber nitrogen alami yang paling baik adalah ekstrak kecambah kedelai $5 \%$ dengan lama fermentasi 10 hari.

\section{ACKNOWLEDGEMENT}

Penulis menyampaikan terima kasih kepada Fauzan Adzami Lumumba dan Novia Resta Burhan yang membantu pelaksanan penelitian.

\section{REFERENCES}

Cahyadi, W. (2007). Kedelai Khasiat dan Teknologi. Jakarta, Bumi Aksara.

Dianawati \& Widowati (2009). Studi kelayakan finansial pengolahan limbah cair tapioka sebagai nata de cassava. Buana Sains, 9(1), 89-95.
Effendi, N. H. (2009). Pengaruh penambahan variasi massa pati (Soluble Starch) pada pembuatan nata de coco dalam medium fermentasi bakteri acetobacter xylinum. Skripsi, Fakultas Matematika dan Ilmu Pengetahuan Alam : Universitas Sumatera Utara.

Hamad, A. \& Kristiono. (2013). Pengaruh penambahan sumber nitrogen terhadap hasil fermentasi nata de coco, Momentum, 9(1), 62-65

Kuncara, Y. A. D. (2017). Pengaruh penggunaan filtrat kecambah kacang kedelai sebagai sumber nitrogen terhadap karakteristik nata de soya berbahan dasar limbah tahu. Skripsi. Program Studi Pendidikan Biologi, Jurusan Pendidikan Matematika dan Ilmu Pengetahuan Alam, Fakultas Keguruan dan Ilmu Pendidikan. Yogyakarta: Universitas Sanata Dharma.

Masri, M. Irhamniah, Triyani A.U, Latif, Rusny. (2020). Comparison of Nata Quality From Cassava Peels (Manihot esculenta), Ladyfinger Bananas Peels (Musa acuminata Colla), and Durian Peels (Durio zibethinus). Elkawnie: Journal of Islamic Science and Technology, Vol. 6 (1), 146155. DOI: 10.22373/ekw.v6i1.6870

Melina M. (2016). Pengaruh penggunaan jus kecambah kacang hijau sebagi sumber nitrogen alternative terhadap karakteristik nata de besusu. Skripsi. Universitas Sanata Dharma, Yogyakarta.

Misgiyarta (2007). Teknologi pembuatan nata de coco. Bogor: Balai Besar Penelitian dan Pengembangan Pascapanen Pertanian.

Muharam, P. G. (2014). Pembuatan nata de cassava dari limbah cair tapioca menggunakan sumber nitrogen ekstrak kacang hijau. Skripsi. Fakultas Pendidikan Matematika Dan Ilmu Pengetahuan Alam Jurusan Pendidikan Kimia. Bandung: Universitas Pendidikan Indonesia.

Musadawati, P.S.,Wiharto, C. \& Kardiman. (2017). Pengaruh pemberian sumber nitrogen dan bibit bakteri acetobacter terhadap kualitas hasil nata de tala. Jurnal Pendidikan Teknologi Pertanian, 3(1), 95 106.

Niarda, A., Tyas A. S. \& Ayu S. U. (2015). Peningkatan kualitas nata de cane dari limbah nira tebu metode budchips dengan penambahan ekstrak tauge sebagai sumber nitrogen. Jurnal Bioteknologi, 12(2), 2933.

Nugraheni, M. (2007). Pengaruh ekstrak kecambah kacang hijau sebagai sumber nitrogen padapemanfaatan limbah tahu 
terhadap karakteristik nata de soya mentah dan limbahnya. Teknologi dan Kejuruan, 30(20), 185-195.

Prastyana, F. (2002). Pembuatan nata de aqua, tinjauan dari jenis dan konsentrasi sumber nitrogen (Urea, NPK, ZA). Skripsi. Universitas Brawijaya, Malang.

Putranto, K. \& Taofik, A. 2017. Penambahan ekstrak toge pada media nata de coco. Jurusan Agroteknologi, Fakultas Sains dan Teknologi. UIN SGD : Bandung.
Putriana, I and Aminah, S. (2013). Mutu Fisik, Kadar Serat dan Sifat Organoleptik Nata de Cassava Berdasarkan Lama Fermentasi. Jurnal Pangan dan Gizi, 4(7), 29-38

Rizal, Hardi M, Dewi M. P, dan Abdullah S. 2013. Pengaruh penambahan gula, asam asetat dan waktu fermentasi terhadap kualitas nata de corn. Jurnal Teknik Kimia Universitas Sriwijaya, 19(1), 34-39. 